\title{
Perlindungan hukum bagi penerima wasiat terhadap notaris yang tidak melaporkan akta wasiat secara elektronik
}

\section{Rizka Octa Pratiwi}

Rizka Octa Pratiwi; Fakultas Hukum Universitas Brawijaya; Jalan MT. Haryono No. 169; Malang; 65145; Jawa Timur; Indonesia.

\section{ARTICLEINFO}

\section{Article history:}

Received 2020-08-09

Received in revised form

2020-09-12

Accepted 2020-12-01

\section{Kata kunci:}

Perlindungan Hukum; Pelaporan

Akta Wasiat; Elektronik.

\section{Keywords:}

Legal Protection; Electronic;

Testament Reporting.

DOI: https:// doi:10.26905/

idjch.v11i3.4267.

\section{How to cite item:}

Pratiwi, R. (2020). Perlindungan hukum bagi penerima wasiat terhadap notaris yang tidak melaporkan akta wasiat secara elektronik. Jurnal Cakrawala Hukum, 11(3). 333-340. doi:10.26905/idjch.v11i3.4267.

\begin{abstract}
Abstrak
Kajian ini fokus membahas terkait perlindungan hukum bagi penerima wasiat terhadap Notaris yang tidak melaporkan akta wasiat secara elektronik dalam website Direktorat Jenderal Administrasi Hukum Umum. Kajian ini menggunakan metode yuridis normatif dengan pendekatan perundang-undangan dan pendekatan analitis. Perlindungan hukum bagi penerima wasiat terhadap Notaris yang tidak melaporkan daftar akta secara elektronik yaitu perlindungan hukum preventif dan perlindungan hukum represif. Apabila dalam pembuatan akta wasiat telah memenuhi syarat dan unsur yang telah ditentukan sebagaimana diatur dalam KUHPerdata dan UU Jabatan Notaris, maka perlindungan hukum terhadap penerima wasiat akan tetap ada dan pelaporan merupakan syarat administratif yang harus dipenuhi.
\end{abstract}

\section{Abstract}

This study focuses on discussing legal protection for beneficiaries of Notaries who do not report a testament on the website of the Directorate General of General Law Administration. This study uses the normative juridical method with the statutory approach and analytical approach. Legal protection for beneficiaries of Notaries who do not report the deed electronically become preventive legal protection and repressive legal protection. If in making a will the deed has fulfilled the requirements and elements that have been determined as regulated in the Civil Code and the Notarial Law, then legal protection for the recipient of the testament will remain and reporting become an administrative requirement that must be fulfilled. 


\section{Jurnal Cakrawala Hukum, Volume 11 No. 3 Desember 2020}

ISSN PRINT 2356-4962 ISSN ONLINE 2598-6538

\section{Pendahuluan}

Berkembangnya zaman menyebabkan manusia selalu menciptakan inovasi-inovasi baru di bidang teknologi. Penggunaan teknologi oleh manusia diawali dengan penggunaan alat-alat sederhana yang dibuat oleh manusia terdahulu. Contohnya adalah telepon kabel yang merupakan teknologi paling inovatif karena dapat menghubungkan manusia untuk saling berkomunikasi dengan manusia lainnya yang terhalang oleh jarak. Namun pada zaman modern saat ini, penggunaan telepon kabel dianggap sebagai hal yang biasa, bahkan penggunaannya dianggap kuno dan sedikit terabaikan akibat munculnya teknologi telekomunikasi terbaru seperti E-mail, Whatsapp, dan Facebook yang berbasis jaringan internet. Adanya media internet yang hadir dalam masyarakat tersebut juga berpengaruh dalam bidang hukum.

Dalam bidang hukum terdapat suatu keadaan dimana adanya peristiwa hukum yang menimbulkan adanya akibat hukum. Sebagai makhluk ciptaan Tuhan manusia pasti mengalami kelahiran dan kematian. Ketika ada seseorang yang meninggal dunia, maka secara otomatis aktiva dan passiva yang dimiliki orang tersebut akan beralih pada orang yang berhak mendapatkannya. Proses tersebut disebut dengan pewarisan. Terdapat beberapa cara ahli waris untuk dapat menerima warisan, di antaranya adalah dengan wasiat melalui surat wasiat. Testamen atau wasiat adalah pernyataan kehendak dari pewaris mengenai apa yang dikehendaki agar terjadi dengan hartanya sesudah pewaris meninggal dunia (Panjaitan, 2016).

"Suatu wasiat pada umumnya berbentuk tertulis yang dituangkan dengan akta di bawah tangan maupun dengan akta otentik oleh seorang Notaris. Akta wasiat ini berisikan pernyataan kehendak sebagai tindakan hukum sepihak, yang berarti pernyataan itu datangnya dari satu pihak. Pewaris dapat membuat surat wasiat dengan cara membuat surat wasiat tersebut di hadapan Notaris, lalu menunjuk siapa ahli warisnya dan berapa besar bagian yang akan diterima oleh ahli "waris tersebut".

Akta wasiat akan berlaku apabila pewaris telah meninggal dunia, selama pewaris masih hidup, pewaris dapat merubah atau mencabut surat wasiat tanpa memerlukan adanya persetujuan siapapun. Suatu wasiat yang termuat dalam akta harus didaftarkan, Akta wasiat tersebut dicatatkan dalam repertorium dan buku daftar wasiat, kemudian dikirim ke Daftar Pusat Wasiat berdasarkan ketentuan dalam Pasal 16 ayat (1) huruf I dan J Undang-Undang No. 2 Tahun 2014 Tentang Jabatan Notaris (selanjutnya disebut UU Jabatan Notaris) mengenai kewajiban notaris berkenaan dengan akta wasiat.

Pasca diterbitkannya Permenkumham No. 60 Tahun 2016 maka pelaporan testament melalui jaringan berbasis internet dengan sistem elektronik. Berdasarkan Pasal 3 Permenkumham No. 60 Tahun 2016 menyebutkan daftar akta wasiat wajib dilaporkan oleh Notaris secara elektronik melalui website resmi Ditjen AHU Kemenkumham. Apabila Notaris tidak melakukan pelaporan daftar akta wasiat secara elektronik maka berdasarkan Pasal 10 Permenkumham No. 60 Tahun 2016 menyebutkan segala hukum yang timbul menjadi tanggung jawab Notaris yang bersangkutan.

Sejalan dengan itu, kewajiban Notaris terkait akta wasiat tertuang dalam Pasal 16 ayat (1) huruf i dan j UU Jabatan Notaris. Bagi Notaris yang melanggar ketentuan tersebut maka akan dikenakan sanksi yang tertuang dalam Pasal 16 ayat (11) UU Jabatna Notaris. Ketentuan tata cara mengenai penjatuhan sanksi tersebut selanjutnya terdapat pada Pasal 91A UU Jabatan Notaris yang selanjutnya akan dijelaskan di Peraturan Menteri. Sedangkan pada Permenkumham No. 60 Tahun 2016 menjelaskan bahwa ketentuan sanksi terkait Notaris yang tidak melaporkan daftar akta wasiat secara elektronik merujuk pada UU Jabatan Notaris. Dari permasalahan hukum tersebut menunjukkan adanya kekosongan norma hukum 


\section{Perlindungan hukum bagi penerima wasiat terhadap notaris yang tidak melaporkan akta wasiat secara elektronik}

Rizka Octa Pratiwi

(rechtsvacuum). Dimana belum terdapat aturan hukum mengenai pelaksanaan tata cara penjatuhan sanksi kepada seorang Notaris. Maka hal tersebut dapat menimbulkan kurangnya perlindungan hukum serta tidak adanya kepastian hukum sehingga dapat menimbulkan kerugian bagi Pewaris dan ahli waris (testamentair).

Berdasarkan uraian latar belakang diatas, tulisan ini akan membahas tentang implikasi yuridis bagi penerima wasiat terhadap Notaris yang tidak melaporkan akta wasiat secara elektronik serta bagaimana bentuk perlindungan hukum bagi penerima wasiat terhadap Notaris yang tidak melaporkan daftar akta wasiat secara elektronik.

\section{Metode}

Metode yang digunakan dalam kajian penelitian ini adalah yuridis normatif dengan pendekatan perundang-undangan (statue approach) dan pendekatan analisa (analytical approach). Jenis sumber bahan hukum yang dipakai berupa bahan hukum primer yaitu peraturan perundang-undangan serta peraturan-peraturan terkait dengan akta wasiat dan bahan hukum sekunder yaitu bukubuku, pendapat para ahli hukum, jurnal-jurnal hukum, artikel internet. Teknik analisis bahan hukum yang digunakan dalam penelitian ini adalah mengolah dengan interpretasi gramatikal, sistematis, dan teleologis dengan analisis preskriptif.

\section{Pembahasan}

\subsection{Implikasi yuridis bagi penerima wasiat terhadap notaris yang tidak melaporkan akta wasiat secara elektronik}

\section{A. Tanggung jawab notaris yang tidak melaporkan akta wasiat secara elektronik dan kendala yang dihadapi}

Tanggung jawab Notaris dalam membuat akta wasiat mencakup keseluruhan dari kewe- nangan, kewajiban, dan larangan yang diatur dalam UU Jabatan Notaris serta formalitas peraturan dalam KUHPerdata. Dalam hal ini, yang dimaksud dengan tanggung jawab terhadap akta wasiat yang dibuatnya adalah bukan mengenai tanggung jawab Notaris terhadap isi akta wasiat, melainkan hanya sebatas tanggung jawab terhadap formalitas atau proses pembuatan akta wasiat tersebut. Seorang Notaris tidak bertanggung jawab terhadap isi akta wasiat, dikarenakan akta wasiat termasuk dalam partij akta. Selama keterangan ataupun perbuatan hukum tersebut tidak bertentangan dengan peraturan perundang-undangan dan norma sosial dalam masyarakat. "Seorang Notaris dapat menolak pembuatan akta jika ketentuan yang terkandung di dalamnya melanggar ketertiban umum, kesusilaan, dan peraturan perundang-undangan Tan Thong Kie, Studi Notariat dan Serba-Serbi Praktek Notaris" (Hoeve, 2007).

Sebelum Pewaris menyatakan kehendak terakhirnya untuk dituangkan dalam sebuah akta wasiat, Notaris berwenang untuk memberikan nasehat ataupun penyuluhan hukum, mengenai apa yang boleh dan apa yang tidak boleh menurut peraturan perundang-undangan yang berlaku sehubungan dengan akta wasiat yang akan dibuatnya serta akibat hukum apa yang nantinya akan timbul apabila kehendak Pewaris tersebut dituangkan dalam sebuah akta. Apabila keterangan yang diberikan oleh para pihak yang bersangkutan tidak benar, maka hal ini bukanlah menjadi tanggung jawab dari Notaris yang bersangkutan, hal tersebut dikarenakan seorang Notaris hanya bertanggung jawab sebatas kebenaran formal. Dengan demikian seorang Notaris tidak bertanggung jawab terhadap isi dan segala akibat hukum dari akta wasiat yang dibuatnya, karena isi dan akibat hukum yang terkandung dalam akta wasiat tersebut merupakan kehendak terakhir dari pemberi wasiat (Pewaris). Dengan demikian seorang Notaris tidak bertanggung jawab terhadap isi dan segala akibat hukum dari akta wasiat yang dibuatnya (Kohar, 1983). 
Notaris bertanggung jawab terhadap para pihak yang berkepentingan pada akta wasiat yang dibuatnya, dimana ketentuan Pasal 1365 dan 1366, serta 1367 KUH Perdata akan terdapat kewajiban untuk membayar ganti kerugian. "Perbuatan melanggar hukum oleh seorang Notaris tidak hanya perbuatan yang langsung melanggar hukum, melainkan juga dapat perbuatan yang secara langsung melanggar peraturan lain, yaitu peraturan mengenai kesusilaan, keagamaan, dan sopan santun dalam masyarakat".

"Akta wasiat yang dibuat oleh Notaris merupakan akta otentik yang sah dan dapat dijadikan sebagai alat bukti yang sempurna. Apabila terdapat pihak yang dirugikan karena adanya akta wasiat yang dibuat oleh Pewaris dihadapan Notaris maka pihak yang dirugikan tersebut dapat menuntut pihak yang menyebabkan kerugian untuk dikenai sanksi secara perdata atas dasar perbuatan melawan hukum. Sanksi ini berupa penggantian biaya, ganti rugi, dan bunga. Dalam hal ini apabila ada pihak yang merasa dirugikan sebagai akibat langsung dari suatu akta yang dibuat oleh Notaris, maka yang bersangkutan dapat menuntut penggantian secara perdata terhadap Notaris yang bersangkutan".

Hal tersebut ditentukan bahwa harus terlebih dahulu dibuktikan beberapa hal yang tercantum dalam Pasal 1365 KUHPerdata.

Notaris yang lalai dalam melaksanakan kewajibannya baik secara sengaja maupun tidak sengaja akan diberikan sanksi yang tercantum dalam Pasal 16 ayat (11) UU Jabatan Notaris, "sanksi pertama adalah peringatan tertulis, kedua adalah pemberhentian sementara, ketiga adalah pemberhentian dengan hormat, keempat adalah pemberhentian secara tidak hormat. Sanksi tersebut merupakan sanksi internal dari organisasi Notaris (Ikatan Notaris Indonesia) yang merupakan pengenaan sanksi secara administrasi sebagai tanggung jawab administratif oleh Notaris (Roeri Andriana, 2017) Sanksi tersebut selanjutnya akan dijatuhkan oleh Majelis Pengawas Notaris sebagai upaya agar Notaris menjalankan jabatannya dengan disiplin dan sesuai dengan peraturan perundang-undangan. Namun pada saat ini belum ada peraturan yang mengatur secara teknis terkait teknik pemberian sanksi bagi Notaris yang melanggar ketentuan tidak melaporkan daftar akta yang dibuatnya secara elektronik kepada Ditjen AHU.

\section{B. Kedudukan akta wasiat jika tidak dilapor- kan secara elektronik oleh notaris}

Daftar akta wasiat yang merupakan salah satu produk hukum Notaris dapat menjadi sebagai alat bukti agar mempunyai kekuatan pembuktian yang sempurna, apabila seluruh prosedur dan tata cara pembuatan akta tersebut terpenuhi (Adjie, 2018). Apabila terdapat prosedur dalam pembuatan akta yang tidak terpenuhi dan prosedur yang tidak dipenuhi tersebut dapat dibuktikan, maka daftar akta wasiat tersebut dapat dinyatakan sebagai akta yang memiliki kekuatan pembuktian sebagai akta di bawah tangan, sehingga apabila daftar akta wasiat telah berkedudukan seperti itu, maka nilai pembuktiannya diserahkan kepada Hakim di Pengadilan.

\subsection{Bentuk perlindungan hukum bagi penerima wasiat notaris yang tidak melaporkan daftar akta wasiat secara elektronik}

\section{A. Pelaporan akta wasiat secara elektronik oleh notaris dan kendala yang dihadapi}

Suatu wasiat merupakan kehendak terakhir dari pewaris sebelum meninggal dunia kepada ahli waris (testamentair) yang dituangkan secara tertulis dalam sebuah akta. Kewenangan seorang Notaris untuk membuat akta otentik mengenai suatu hal yang dikehendaki oleh pihak yang berkepentingan 


\section{Perlindungan hukum bagi penerima wasiat terhadap notaris yang tidak melaporkan akta wasiat secara elektronik}

Rizka Octa Pratiwi

dinyatakan dalam Pasal 15 UU Jabatan Notaris. Salah satu produk hukum dari Notaris adalah akta wasiat. Seorang Notaris berkewajiban untuk membuat akta wasiat sesuai dengan yang dikehendaki oleh Pewasiat. Akta wasiat dibuat, didaftarkan, dan dilaporkan oleh Notaris serta dicatat dalam repertorium dan buku daftar wasiat. Hal tersebut diatur dalam Pasal 16 ayat (1) huruf i, j, dan k dalam UU Jabatan Notaris.

Pada ketentuan dalam Pasal 16 ayat (1) huruf I dan j UU Jabatan Notaris secara tegas mengatur kewajiban Notaris untuk membuat daftar akta atau daftar nihil yang berkenaan dengan wasiat pada setiap bulannya. Kemudian melaporkan daftar akta tersebut kepada Kementerian Hukum dan Hak Asasi Manusia Republik Indonesia dengan jangka waktu paling lambat pada tanggal 5 setiap bulannya.

pendaftaran wasiat, terdapat beberapa ketentuan Peraturan yang mengatur antara lain yaitu Ordonansi dpw atau pusat wasiat (ordonnantie op het Centraal Testarnentenregister) S.1920-305 jo.1921568 (mb. 1 Januari 1922) (Ord.15 April 1920), Burgerlijk Wetboek, Undang Undang Nomor 2 Tahun 2014 Tentang Perubahan Atas Undang Undang Nomor 30 Tahun 2004 Tentang Jabatan Notaris, dan Pasal 41-42 OV. Permenkumham No. 60/2016.

Pada awalnya sistem pendaftaran wasiat dilakukan secara manual dengan mengirimkan daftar akta atau daftar nihil ke Daftar Pusat Wasiat pada kementerian yang menyelenggarakan urusan pemerintahan bidang hukum dalam waktu 5 (lima) hari pada minggu pertama setiap bulan berikutnya melalui pos ataupun datang secara langsung ke loket pada Kementerian Hukum dan Hak Asasi Manusia. Namun apabila tidak ada wasiat yang dibuat, maka Buku Daftar Wasiat tetap harus dibuat dan dilaporkan dengan tulisan "NIHIL". Pendaftaran wasiat ini selanjutnya dibuatkan Surat Keterangan Wasiat (SKW). Hal tersebut dirasa cukup penting karena dapat mempengaruhi telah terdaftar atau tidaknya wasiat di Subdirektorat
Harta Peninggalan Surat Keterangan Wasiat. Surat Keterangan Wasiat ini merupakan sebuah surat yang menerangkan bahwa semasa hidupnya Pewaris pernah membuat wasiat atau tidak pernah membuat wasiat. Apabila wasiat dilaporkan oleh Notaris ke Daftar Pusat Wasiat, maka Subdirektorat Harta Peninggalan akan mencatat bahwa wasiat Pewaris telah terdaftar. Namun apabila terdapat wasiat dan tidak dilaporkan, maka berakibat wasiat tersebut menjadi tidak terdaftar di Subdirektorat Harta Peninggalan hal ini dapat mengakibatkan munculnya permasalahan baru apabila ternyata diketahui bahwa harta warisan ternyata telah dijual oleh pihak tertentu yang tidak bertanggung jawab. Apabila hal ini terjadi, maka Notaris dapat dimintakan pertanggungjawabannya.

Berdasarkan surat edaran yang diterbitkan oleh Ditjen AHU (Direktorat Jenderal Administrasi Hukum Umum) yang diumumkan pada tanggal 22 Juni 2015 di website Direktorat Jenderal Administrasi Hukum Umum dan diikuti oleh terbitnya Peraturan Kementerian Hukum dan Hak Asasi Manusia No. 60 Tahun 2016 Tentang Tata Cara Pelaporan Wasiat dan Permohonan Penerbitan Surat Keterangan Wasiat Secara Elektronik bahwa saat ini Notaris wajib untuk mendaftarkan dan melaporkan wasiat secara elektronik. Maka Daftar Pusat Wasiat Subdirektorat Harta Peninggalan Direktorat Perdata tidak lagi menerima pengiriman laporan daftar akta berkenaan dengan wasiat secara manual.

Notaris memiliki kewajiban-kewajiban lain yang harus dipenuhi sesuai dengan peraturan yang berlaku. Kewajiban tersebut adalah kewajiban untuk membuat daftar akta atau daftar nihil yang berkaitan dengan wasiat dan melaporkan daftar tersebut secara elektronik dalam website resmi Ditjen Administrasi Hukum Umum Kementerian Hukum dan Hak Asasi Manusia. Kewajiban Notaris untuk melaporkan daftar akta wasiat/daftar nihil secara elektronik terdapat dalam Pasal 3 Peraturan Kementerian Hukum dan Hak Asasi Manusia No. 60 Tahun 2016. 


\section{Jurnal Cakrawala Hukum, Volume 11 No. 3 Desember 2020}

ISSN PRINT 2356-4962 ISSN ONLINE 2598-6538

Saat ini Direktorat Jenderal Administrasi Hukum Umum memberlakukan sistem pendaftaran wasiat secara elektronik. Kewajiban Notaris ini bertujuan untuk memberikan jaminan perlindungan hukum dan kepastian hukum terhadap kepentingan ahli waris. Untuk dapat mengakses dalam website ini, Notaris harus menjalankan prosedur yaitu harus mengajukan permohonan terlebih dahulu dan telah terdaftar dalam Direktorat Jenderal Administrasi Hukum Umum yang kemudian akan diberikan user id dan password kepada Notaris yang bersangkutan.

Dengan diberlakukannya sistem pendaftaran akta wasiat secara elektronik ini, maka Pusat Wasiat Subdit Harta Peninggalan Direktorat Perdata tidak lagi menerima pengiriman laporan daftar akta yang berkenaan dengan wasiat secara manual. Apabila Notaris melakukan pelaporan yang berkenaan dengan wasiat secara manual, maka laporan tersebut tidak akan terdata dalam database wasiat elektronik, sehingga informasi tentang ada atau tidaknya daftar wasiat pada Pusat Daftar Wasiat menjadi tidak akurat. Daftar Pusat Wasiat Subdirektorat Harta Peninggalan Direktorat Perdata secara administratif hanya mendata setiap laporan daftar akta wasiat yang oleh undangundang diwajibkan dilaporkan oleh Notaris dalam jangka waktu tertentu.

Pelaporan wasiat secara elektronik yang merupakan kewajiban seorang Notaris tidak sepenuhnya berjalan dengan baik sesuai dengan rencana Pemerintah. Ada kalanya hambatan yang dialami oleh para Notaris dalam perjalanannnya melaporkan daftar akta wasiat secara elektronik. Hambatan tersebut muncul dari diri pribadi ataupun dari luar pribadi Notaris tersebut diantaranya adalah tidak stabilnya signal atau jaringan internet, sehingga Notaris menjadi sulit untuk melaporkan secara elektronik yang mengandalkan jaringan internet, adanya kesalahan dalam pengisian pada form online pelaporan daftar akta wasiat dalam website resmi Ditjen AHU, ketidakpahaman
Notaris tentang bagaimana alur dan prosedur pelaporan daftar akta wasiat secara elektronik dan cara untuk mengakses website resmi Ditjen AHU dan lainnya. Dimana Hal-hal di atas dapat berdampak pada pelaporan daftar akta wasiat secara elektronik yang dilakukan oleh Notaris, yaitu dimana datanya bisa menjadi tidak akurat, maupun akta wasiat menjadi tidak terdaftar akibat kurang tersedianya jaringan internet yang stabil.

\section{B. Perlindungan hukum bagi penerima wasiat terhadap notaris yang tidak melaporkan daftar akta wasiat secara elektronik}

Notaris tanggung jawab apabila akta yang dibuatnya terdapat kesalahan dan pelanggaran yang sengaja oleh Notaris. Sebaliknya, apabila unsur kesalahan atau pelanggaran tersebut terjadi yang disebabkan oleh para penghadap, maka sepanjang seorang Notaris melaksanakan kewenangan sesuai dengan peraturan yang berlaku, maka Notaris yang bersangkutan tidak dapat dimintakan pertanggungjawabannya. Hal tersebut dikarenakan seorang Notaris cuma mencatat apa yang diinfokan oleh para para pihak pengahadap untuk dituangkan dalam sebuah akta. Keterangan dan atu informasi palsu yang disampaikan oleh para pihak adalah menjadi tanggung jawab para pihak. Dapat dikatakan Notaris dapat dimintakan pertanggungjawabannya apabila telah terbukti melakukan tindak pemalsuan terhadap akta yang dibuatnya. Dalam contoh kasus, secara singkat seorang Notaris dinyatakan telah melakukan tindak pidana pemalsuan terhadap akta yang dibuatnya. Notaris telah melakukan perubahanperubahan berupa pengurangan serta menghilangkan isi yang ada dalam minuta akta. Akibat dari tindakan Notaris tersebut tentunya dapat menimbulkan kerugian materiil bagi para pihak (Adjie, 2011). 


\section{Perlindungan hukum bagi penerima wasiat terhadap notaris yang tidak melaporkan akta wasiat secara elektronik \\ Rizka Octa Pratiwi}

Permenkumham No. 60 Tahun 2016 yang mewajibkan seorang Notaris untuk melaporkan daftar akta wasiat yang dibuatnya secara elektronik. Artinya bahwa setiap daftar akta wasiat yang dibuat oleh Notaris harus dilaporkan secara elektronik oleh Notaris yang bersangkutan kepada website resmi Ditjen AHU. Apabila Notaris yang bersangkutan tidak melaporkan daftar akta wasiatnya yang dibuatnya secara elektronik, maka terhadap akta wasiat tersebut tetaplah menjadi akta otentik yang berkekuatan hukum sempurna dan mengikat, tetapi kurang dalam pemenuhan syarat administrasi yaitu pelaporannya secara elektronik.

Akibat hukum yang ditimbulkan apabila seorang Notaris tidak melakukan pelaporan daftar akta wasiat secara elektronik akta itu cuma mengikat para pihak pembuat surat wasiat dan tidak mengikat terhadap pihak ketiga. Karena akta wasiat yang tidak dilaporkan secara elektronik tersebut tidak memenuhi asas publisitas dalam penyampaian laporan akta wasiat yang wajib dilakukan oleh Notaris. Jika wasiat tersebut tidak dilaporkan secara elektronik dalam website resmi, maka para ahli waris akan membuat surat keterangan waris, dan akta wasiat tidak akan terdeteksi oleh Kemenkumham Akibatnya Notaris yang akan membuat surat keterangan waris tidak mencantumkan akta wasiat, karena setelah dicek di Kementerian Hukum dan HAM akta waris tidak pernah dibuat. Akibatnya wasiat tidak mengikat bagi pihak ketiga. Hal ini membuat para ahli waris yang telah dirugikan berhak untuk menuntut ganti rugi kepada Notaris yang membuat surat keterangan wasiat karena Notaris tidak melaksanakan kewajibannya untuk melaporkan akta wasiatnya secara elektronik dalam website resmi Ditjen AHU. Pihak yang dirugikan dalam hal ini adalah ahli waris.

Perlindungan hukum bagi penerima wasiat terhadap Notaris yang tidak melaporkan daftar akta wasiat yang dibuat olehnya secara elektronik dapat melalui bentuk perlindungan hukum preven- tif melalui peraturan perundang-undangan dan melalui perjanjian. Perlindungan hukum preventif melalui peraturan perundang-undangan merupakan perlindungan hukum yang diberikan dengan cara mereformulasikan pasal yang terdapat pada Permenkumham No. 60 Tahun 2016 yang dilanjutkan untuk membentuk peraturan pelaksana baru yang mengatur mengenai tata cara pelaporan daftar akta wasiat yang dilakukan secara elektronik. Sedangkan perlindungan hukum preventif melalui perjanjian dapat dilakukan dengan cara menganalisis klausul yang terdapat dalam daftar akta wasiat, misalnya ketetentuan kewajiban Notaris untuk melaporkan daftar akta yang dibuatnya terdapat dalam Pasal 11 ayat (1) huruf I UU Jabatan Notaris yang selanjutnya diatur bahwa pelaporan daftar akta wasiat dilakukan secara elektronik yang termuat dalam Pasal 3 Permenkumham No. 60 Tahun 2016 yang menyatakan bahwa pelaporan daftar akta atau daftar nihil dilakukan secara elektronik melalui website resmi Ditjen Admiistrasi Hukum Umum pada Kementerian Hukum dan Hak Asasi Manusia yang disampaikan dalam jangka waktu tertentu.

Pokok permasalahan terhadap adanya kemungkinan terjadinya kesalahan yang dilakukan oleh seorang Notaris berkaitan dengan tidak dilaporkannya daftar akta wasiat secara elektronik, akan dapat merugikan pihak penerima waris (testamentair). Dalam menjalankan tugas dan profesinya, seorang Notaris dapat melakukan sebuah kesalahan, kesalahan tersebut dapat dibedakan menjadi kesalahan yang bersifat pribadi yang berasal dari dalam diri Notaris tersebut dan kesalahan dalam melaksanakan jabatannya (Adjie, 2011).

Pentingnya perlindungan hukum bagi Notaris adalah untuk menjaga keluhuran harkat dan martabat jabatan seorang Notaris itu sendiri, untuk merahasiakan keterangan yang termuat dalam akta yang dibuatnya guna menjaga kepentingan para pihak yang ada didalam akta tersebut, dan untuk 


\section{Jurnal Cakrawala Hukum, Volume 11 No. 3 Desember 2020}

ISSN PRINT 2356-4962 ISSN ONLINE 2598-6538

menjaga minuta atau surat-surat yang dilekatkan pada minuta akta, serta protokol Notaris dalam penyimpanannya.

\section{Simpulan}

Implikasi yuridis bagi penerima wasiat terhadap Notaris yang tidak melaporkan akta wasiat secara elektronik adalah berkaitan dengan tanggung jawab Notaris dalam pembuatan akta otentik berupa akta wasiat yang tidak dilaporkan secara elektronik dalam website Direktorat Jenderal Administrasi Hukum Umum Pasca Terbitnya Peraturan Kementerian Hukum dan Hak Asasi Manusia No. 60 Tahun 2016 Tentang Tata Cara Pelaporan Wasiat dan Permohonan Penerbitan Surat Keterangan Wasiat Secara Elektronik adalah Notaris yang bersangkutan dapat dikenai sanksi, baik berupa sanksi perdata maupun sanksi administratif. Sanksi perdata dapat berupa penggantian biaya, ganti rugi, dan bunga kepada pihak yang dirugikan. Sedangkan sanksi administratif dapat berupa peringatan tertulis, pemberhentian sementara, pemberhentian dengan hormat, dan pemberhentian dengan tidak hormat oleh Majelis Pengawas Pusat atas usul Majelis Pengawas Wilayah dan Majelis Wilayah Daerah. Selain itu, Notaris yang tidak melaporkan daftar akta wasiatnya dalam website Direktorat Jenderal Administrasi Hukum Umum berarti Notaris tersebut tidak melaksanakan kewajiban sesuai yang diatur dalam UU Jabatan Notaris dan Peraturan Kementerian Hukum dan Hak Asasi Manusia No. 60 Tahun 2016.

Bentuk perlindungan hukum bagi penerima wasiat berkaitan dengan Notaris yang tidak melaporkan daftar akta secara elektronik terbagi menjadi perlindungan hukum preventif dan perlindungan hukum represif. Perlindungan hukum terhadap penerima wasiat akan tetap ada sepan- jang pembuatan akta wasiat tersebut telah memenuhi ketentuan syarat-syarat dan unsur yang telah ditentukan sebagaimana diatur dalam KUHPerdata dan UU Jabatan Notaris. Pelaporan secara elektronik ke dalam website Direktorat Jenderal Hukum Umum ditentukan sebagai syarat administratif yang tetap harus dipenuhi dan sebagai kewajiban Notaris.

\section{Daftar pustaka}

Adjie, Habib. 2009. Sanksi Administratif Terhadap Notaris Sebagai Pejabat Publik, Cet 2. Refika Aditama. Bandung.

Adjie, Habib. 2011. Majelis Pengawas Notaris Pejabat Tata Usaha Negara. Refika Aditama. Bandung.

Adjie, Habib. 2011. Hukum Notaris Indonesia Terhadap UU No. 30 Tahun 2004 Tentang Jabatan Notaris. Refika Aditama. Bandung.

Kohar, A. 1983. Notaris Dalam Praktek Hukum. Alumni. Bandung.

Panjaitan, Debora Claudia. 2016. Pembatalan Akta Wasiat Sebagai Akibat Perbuatan Melawan Hukum Dilakukan. Premise Law Jurnal. 21.

Tadu, O. I. L. 2017. Perlindungan hukum terhadap anak luar kawin dalam pembagian waris adat Toraja. Jurnal Cakrawala Hukum, 8(1), 96-105.

Susilaningsih, T. 2017. Terbitnya Sertifikat Hak Atas Tanah Akibat Peralihan Hak Yang Cacat Hukum. Jurnal Cakrawala Hukum, 8(1), 118-128.

Sjaifurrachman dan Habib Adjie. 2011. Aspek Pertanggungjawaban Notaris dalam Pembuatan Akta. Mandar Maju. Bandung.

Sjaifurrachman, Habib Adjie. 2011. Aspek Pertanggungjawaban Notaris Dalam Pembuatan Akta Cetakan Ke-1. Mandar Maju. Bandung.

Wijk, Van dan Willem Konijnenbelt. 1990. Hoofdstukken van Administratiefrecht, Uitgeverij Lemma B.V. Utrech. 